\title{
XIV. Description of a machine for drawing bolts in and out of ships
}

\section{Capt. William Bolton}

To cite this article: Capt. William Bolton (1799) XIV. Description of a machine for drawing bolts in and out of ships, Philosophical Magazine Series 1, 3:10, 189-190, DOI: 10.1080/14786449908676981

To link to this article: http://dx.doi.org/10.1080/14786449908676981

曲 Published online: 18 May 2009.

Submit your article to this journal $\lceil\pi$

ЏII Article views: 2

Q View related articles $\square$ 
XIV. Defcription of a Macbine for drawing Bolts in and out of Sbips. Invented by Capt. Willtam Bolton of the Navy. From Tranfactions of the Society for the Encouragement of Arts, \&c. Vol. XVI.

HE gold medal was voted to Captain Bolton for this contrivance, a model of which is preferved for the ufe of the Public in the Society's repofitory.

A A A A A (Plate IV.) is the frame of the machine. $B$, a cylindrical tube, having a female forew in the infide. $\mathrm{C}$, a wheel with teeth attached to the cylinder B. D, an endlefs fcrew adapted to the wheel $C$. E, handle of the winch. F, the bolt drawing out. G G, blocks to fupport the frame. $\mathrm{H}$, a hollow piece of fteel, having on its outfide a male forew, whole threads work within the female ferew in the cylinder B. To this piece of fteel the bolt is to be riveted. I, a femicircular piece of fteel, which is to be introduced into the notches on $\mathrm{H}$, when a fimilar notch has been cut in the head of the copper bolt, which by this means is prevented from turning in $H$, while drawing. $K$, the bolt, as prepared to receive the machine. $\mathrm{L}$, a fteel bar, fomewhat fmaller than the bolt to be drawn, having at one end a male ferew, A, and at the other end another male forew that fits into the female forew in B. M, a fection of a male fcrew, having a fquare hole larger than the bolt. $\mathrm{N}$, a bolt with a male ferew at one end ready to be drawn in.

The machine, of which a plate is annexed, confins of a frame fupporting a cylindrical female forew tube. On this tube is monnted a wheel with teeth adapted to an endlefs forew fitted to the frame, and worked by a handle.

\section{To draw the Bolt out.}

The head of the bolt mult be cut off, and a hole made in the timber big enough to receive the male forew $\mathrm{H}$, which 


\section{Phelo. Mag. Pl, IV, Vol. III.}

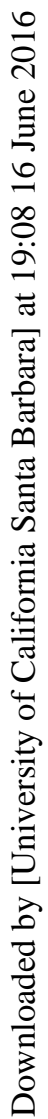

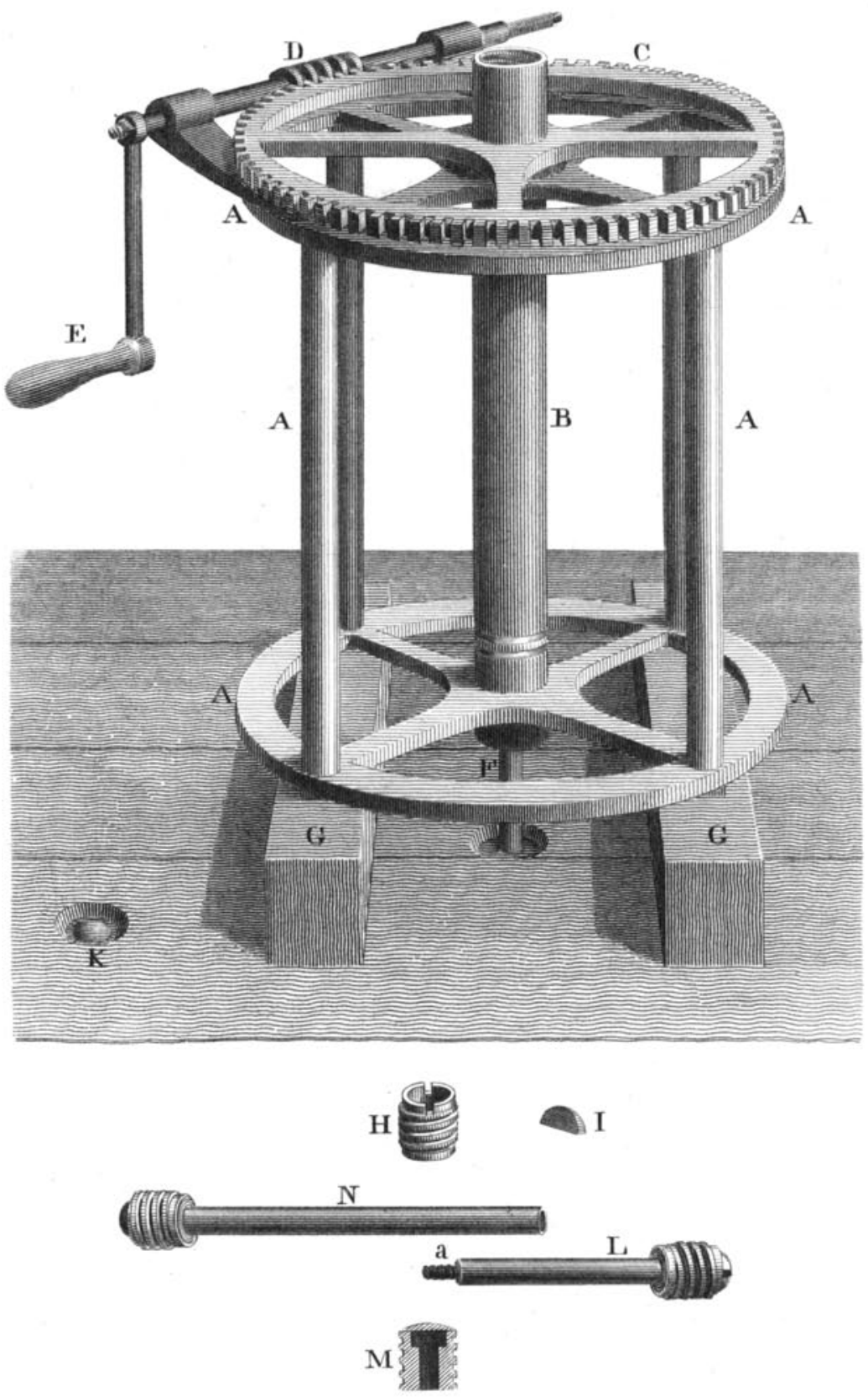


is put over the bolt: a hit is then to be made, either by faw or cold chiffel, in the head of the bolt, to receive the key $I$, and which correlponds to the nit in $H$ : the bolt head is then to be riveted as firmly as poffible upon $H$ : the cylindrical tube, $B$, is then to be fcrewed on, turning the whole machine round till it can be done no longer, when the endlefs fcrew is to be ufed. If the machine is of a proper ftrength, and the riveting well done, the power is fuch as to extract the bolt or break it, but generally it will be drawn out uninjured.

\section{To draw Bolts into Sbips.}

It will be neceffary to have a bar, $\mathrm{L}$, which $\mathrm{I}$ recommend to be made of fteel, long enough to pafs from the infide to the outfide of the fhip, and fomewhat fmaller than the copper bolt intended to be drawn in. This may be called a conductor. On one end fhould be a male fcrew, $a$; the bolt to be drawn in fhould be tapped at one end to receive the male forew, $a$, on the conduetor, and at the other end fhould be another male fcrew that fits into the female fcrew in $B$; after which the operation is the fame as drawing a bolt out, and the machine fhould be applied accordingly. When the bolt arrives at its deftined place, it may be fecured on the infide by a nut, which is as good a way of faftening as clinching, and much more expeditious.

This machine, though only of the height of eighteen inches, will draw bolts in or out of any length; for, after the bolt has rifen to the top of the tube, it will only be neceffary to forew the machine back, and follow up the work with blocks of timber, as reprefented in the drawing.

Note. If the upper part of the hole in $\mathrm{H}$ be made fquare, larger than the round hole as fhewn at $M$, and the head of the bolt riveted into it, it will do away the neceffity of the key, 1 , render the machine lefs complicated, and fave much time and trouble. 